IZA DP No. 6082

Publishing Trends in Economics across

Colleges and Universities, 1991-2007

Anne E. Winkler

Sharon G. Levin

Paula E. Stephan

Wolfgang Glänzel

October 2011 


\title{
Publishing Trends in Economics across Colleges and Universities, 1991-2007
}

\author{
Anne E. Winkler \\ University of Missouri St. Louis and IZA \\ Sharon G. Levin \\ University of Missouri St. Louis \\ Paula E. Stephan \\ Georgia State University, NBER and University of Torino \\ Wolfgang Glänzel \\ MSI, ECOOM, K.U. Leuven \\ Discussion Paper No. 6082 \\ October 2011 \\ IZA \\ P.O. Box 7240 \\ 53072 Bonn \\ Germany \\ Phone: +49-228-3894-0 \\ Fax: +49-228-3894-180 \\ E-mail: iza@iza.org
}

Any opinions expressed here are those of the author(s) and not those of IZA. Research published in this series may include views on policy, but the institute itself takes no institutional policy positions.

The Institute for the Study of Labor (IZA) in Bonn is a local and virtual international research center and a place of communication between science, politics and business. IZA is an independent nonprofit organization supported by Deutsche Post Foundation. The center is associated with the University of Bonn and offers a stimulating research environment through its international network, workshops and conferences, data service, project support, research visits and doctoral program. IZA engages in (i) original and internationally competitive research in all fields of labor economics, (ii) development of policy concepts, and (iii) dissemination of research results and concepts to the interested public.

IZA Discussion Papers often represent preliminary work and are circulated to encourage discussion. Citation of such a paper should account for its provisional character. A revised version may be available directly from the author. 


\section{ABSTRACT}

\section{Publishing Trends in Economics across Colleges and Universities, 1991-2007}

There is good reason to think that non-elite programs in economics may be producing relatively more research than in the past: Research expectations have been ramped-up at non-PhD institutions and new information technologies have changed the way academic knowledge is produced and exchanged. This study investigates this question by examining publishing productivity in economics (and business) using data from the Web of Science (Knowledge) for a broad set of institutions - both elite and non-elite - over a 17-year period, from 1991 through 2007. Institutions are grouped into six tiers using a variety of sources. The analysis provides evidence that non-elite institutions are gaining on their more elite counterparts, but the magnitude of the gains are small. Thus, the story is more of constancy than of change, even in the face of changing technology and rising research expectations.

JEL Classification: A14, I23

Keywords: higher education, research productivity, publishing trends, inequality

Corresponding author:

Anne E. Winkler

Department of Economics

University of Missouri-St. Louis

One University Boulevard

St. Louis, MO 63130

USA

E-mail: awinkler@umsl.edu

\footnotetext{
* This research is funded by a grant from the Andrew W. Mellon Foundation titled "The Diffusion of Information Technology across Institutions of Higher Education: Effects on Productivity by Type of Institution and Gender." The authors thank Erin Coffman for expert research assistance.
} 


\section{Introduction}

In recent years a “cottage industry” in economics has developed focused on compiling rankings of institutions (departments), based on article or citation counts (Thursby 2000). ${ }^{1}$ Such counts typically focus on research productivity at $\mathrm{PhD}$ institutions. Others have looked at the concentration of publishing in top journals among economists at the most elite institutions (for example, Hodgson \& Rothman, 1999; Kocher \& Sutter, 2001; and Ellison, 2011). But, what has been happening to research productivity across a broader set of institutions over the last 20 or so years? There is good reason to think that non-elite programs in economics may be producing relatively more research than in the past, what we call "nibbling at the lion's share.” First, research expectations have been “ramped-up” at non-PhD institutions (Laband \& Tollison, 2003). Moreover, the development of information technologies has changed the way academic knowledge is produced and exchanged.

This study investigates this question, not heretofore addressed in the literature, by taking advantage of a unique data set constructed by the authors that contains publication data obtained from Thomson Reuters Web of Knowledge (formerly known as the ISI Web of Science) for economics and business for a broad set of institutions_-both elite and non-elite—over a 17-year period, from 1991 through 2007. These data provide institutional counts of business and economics publications in ISI-selected journals, as well as those published in the top 5\% most cited journals, thereby providing information on quality. These data allow us to examine publishing levels across institutions as well as to look at indicators of nibbling — changes in publishing concentration (inequality) over time and changes in the ratio of mean publications by

\footnotetext{
${ }^{1}$ Indeed, Coupé, (2003) points to the growing interest of economists studying our own profession, in a variety of dimensions.
} 
tier. This research also fits within a larger body of research that has studied the "outer circle” of science, typically populated by women and minorities located at non-elite institutions (Zuckerman, Cole \& Bruer, 1991).

The study proceeds as follows. Section II summarizes the previous literature on publishing patterns in economics and presents the nibbling hypothesis that non-elite institutions may be making productivity gains relative to their more elite counterparts. Section III outlines the data and methodology used. Findings and conclusions are presented in Section IV and Section V.

III. Previous Work and the Nibbling Hypothesis

The economics profession has focused substantial attention on itself (see Coupé, 2004). Studies have focused on quantity, quality, institutional concentration, co-authorship and multiinstitution collaboration, and explanations for trends and variations across institutions. Most, but not all, of the research on publishing productivity has focused on $\mathrm{PhD}$ institutions. Important exceptions are Hartley \& Robinson (1997) and Bodenhorn (1997; 2003), which looked at select liberal arts institutions. ${ }^{2}$ Institutional rankings have been constructed based on page or article counts, typically adjusted for journal quality (e.g. Scott \& Mitias, 1996; Dusansky \& Vernon, 1998, Kalaitzidakis et al. 2003; Coupé, 2003; Grijalva \& Nowell, 2008), based on surveys (US News \& World Report, National Research Council, 1995, 2010), and most recently, based on PhD placements (Amir \& Knauff, 2008).

\footnotetext{
${ }^{2}$ While some studies have looked at Master's programs in economics, including McCoy and Milkman (2006), they have not focused on research productivity.
} 
There appears to be consensus on the following points: 1) rankings of $\mathrm{PhD}$ programs based on survey data or publications are highly correlated (Thursby, 2000); 2) $\mathrm{PhD}$ institutions that are ranked at the top remain in that position over time, while there is much more movement among less-elite PhD. institutions (Scott \& Mitias, 1996; Thursby, 2000; Coupé, 2003); 3) institutions that have rankings that are closely clustered together do not tend to be statistically different (Thursby, 2000); 4) there is substantial positive correlation between rankings and department size (Coupé, 2003); and 5) rankings of institutions (departments) are more "robust" than rankings of individuals since average department productivity varies less than the productivity of one person (Coupé, 2003).

Other work has tackled the question of journal rankings and the quality of what is produced (e.g. Coupé, 2003; Kalaitzidakis et al., 2003; Engemann \& Wall, 2009; and Wall, 2009). A common method and the one relied on for the analysis here, focuses on citations. This approach is not without its limitations. As noted by Coupé (2003), citations typically include self-citations, while citations to books are generally not included. Moreover, citations distributions for journals tend to be skewed by the inclusion of exceptionally-highly cited papers, “stars” (Wall, 2009). Nonetheless, Wall (2009) finds that a simple measure of journal quality using total journal citations (such as the one employed here) is highly correlated (.98) with an hindex which measures overall impact of a journal and explicitly adjusts for "stars.”3

Research has also consistently demonstrated considerable concentration of authors in top journals at the country-level and institution-level. Previously Hodgson \& Rothman (1999) found

\footnotetext{
${ }^{3}$ Hirsch (2005) created the h-index to measure an individual researcher's output. Braun, Glanzel, and Schubert (2006) subsequently developed an h-index for journals.
} 
that ten U.S. universities (Harvard, MIT, Chicago, University of Pennsylvania, Stanford, Northwestern, Princeton, Berkeley, Michigan, UC-San Diego) produced slightly more than 25\% of all publications in the top 15 journals examined for 1995. This same figure is corroborated by Kocher \& Sutter (2001) in their study of over 3,000 articles published in 15 top journals averaged over 5 years (1977, 1982, 1987, 1992, and 1997). Furthermore, Kocher \& Sutter found that U.S. authors accounted for the top $72 \%$ of all “top 15 journal” authors over these same 5 years, evidence of substantial U.S. concentration from a country-wide perspective. Nonetheless, Cardoso, Guimaraes \& Zimmerman (2010) found that Europe is making inroads. More recently, Amir \& Knauff (2008) studied a different metric of institutional quality, PhD placements. They found that economics PhD graduates of seven U.S. universities (MIT, Harvard, Stanford, Princeton, Chicago, Yale, and UC-Berkeley) consistently placed at the top in the various placement measures constructed, and for the most part, well ahead of other U.S. institutions. ${ }^{4}$

Other research directly bears on what we have termed the "nibbling” hypothesis—-that less elite institutions may be making productivity gains relative to their more elite counterparts. First, a number of studies have focused on the IT revolution and, specifically, how it is changing the way in which research is produced and disseminated in economics and business, as well as throughout academia. For one, IT has been found to enhance research productivity and coauthorship (e.g. see Butler, Butler \& Rich, 2008; Hamermesh \& Oster, 2002; Kim, Morse \& Zingales, 2009; Winkler et al. 2011). Furthermore, it has been argued that IT may have a “democratizing” effect and may have benefited some subgroups (e.g. those at lower-tier institutions) relative to others, thereby helping to level the research “playing field.” IT provides

\footnotetext{
${ }^{4}$ One of the measures examined by Amir \& Knauff (2008) focuses on graduates since 1990 placed in economics departments only. For this measure, Northwestern is also included in the top set. See Table 1 of Amir \& Knauff (2008).
} 
researchers at non-elite institutions with access to knowledge and ability to communicate and network “virtually.” It also, as noted above, facilitates access to data and materials (e.g. JSTOR). Indeed, quite a number of studies have found that IT enhances the research productivity of individual scientists located outside of the “inner circle” (e.g. Agrawal \& Goldfarb, 2008; Kim, Morse \& Zingales, 2009; Ding et al. 2010). Notably, however, Winkler et al. (2011) did not find a democratizing effect of IT at the institutional level; the explanation offered is that although IT is beneficial to active researchers working at lower-tier institutions, the fraction of research-active scientists (who would be affected by IT) at these institutions is relatively low.

Apart from the role of IT, two other factors may have affected the publication landscape, thereby enabling nibbling by the non-elites. First, increases in research expectations, notably among non-elite institutions, both in the U.S. (Zivney \& Bertin, 1992; Whitman, Hendrickson \& Townsend, 1999; and Laband \& Tollison, 2003) and around the globe (Graber, Launov \& Walde, 2008) have been noted. ${ }^{5}$ Laband \& Tollison point to reduced teaching loads, even at more teaching-oriented institutions, as having facilitated this shift. ${ }^{6}$ From an individual standpoint, evidence also suggests that research productivity confers rewards in the form of higher salary, also serving to increase incentives for faculty at virtually all institutions to

\footnotetext{
${ }^{5}$ Franzoni, Scellato and Stephan (2011), for example, examine how changing incentives to publish, especially in English, have affected publishing patterns outside the United States.

${ }^{6}$ An exception is Harter, Becker and Watts (2004). In their study of a broad set of baccalaureate institutions, they found that from 1995 to 2000 self-reported time devoted to teaching increased and time devoted to research decreased.
} 
reallocate time and effort to research (Hamermesh, 1989; and Ragan,Warren \& Bratsberg, 1999, as cited in Coupé, 2004). ${ }^{7}$

Second, another contributing factor to increased research productivity at non-elite institutions may be related to labor market conditions for new economics $\mathrm{PhDs}$. For the period from 2000 on, but for selected earlier years as well, Oyer (2006) identifies periods during which the number of job seekers (as measured by CVs in job market books) exceeded the number of positions available in Jobs for Economists (JOE). To the extent that top candidates cannot get positions at the highest ranked institutions they end up with positions outside this group. Their presence may increase productivity at their current institutions. ${ }^{8}$ However, it is possible that their productivity may be diminished (compared to the counterfactual if they had landed a top position) by access to fewer institutional resources and higher teaching loads. ${ }^{9}$ Further, Oyer (2006) makes the point that “where you land” may influence post-graduate school human capital investments regarding teaching vs. research. In the data at hand, we cannot disentangle these various explanations, but we can explore the extent to which “nibbling” has occurred.

\section{Data and Methodology \\ $\underline{\text { Institutional Data and Publication Measures }}$}

The starting universe for the publication data are the set of 1,348 four-year colleges and universities that have been in existence since 1980 and have not undergone a "substantial"

\footnotetext{
${ }^{7}$ What is more debated is whether increases in research productivity across the profession have resulted in greater quality of publications. Impact on research quality is questioned by Laband \& Tollison (2003). They observe that the percentage of uncited papers (“dry holes”) has remained constant. Mayer (2004) suggests flaws in this interpretation, pointing out that other papers may be cited more frequently than in the past.

${ }^{8}$ A notable statistic provided by Wu (1995) is that $45.8 \%$ of the positions in economics at the top 25 liberal arts institutions were held by faculty with doctorates from the top 10 schools (59.9\% from the top 20 schools).

${ }^{9}$ In earlier work, Long (1978) also found that productivity is very dependent on location.
} 
change in structure such as a major acquisition or merger. ${ }^{10}$ Given that the purpose of the study is to examine publication productivity, we further restrict this group to those classified by the Carnegie Foundation (1994) as Doctoral, Master’s, and Comprehensive, plus select liberal arts institutions, as identified by Bodenhorn (2003). This results in a set of 771 institutions. Further details are provided below in the section on assignment of institutions to tiers.

Institutional publication data on economics and business come from the Thomson Reuters Web of Knowledge (formerly referred to as the ISI Web of Science) for the period 19912007. The disciplines are defined according to a classification scheme developed by Glanzel \& Schubert (2003), category 01, “Economics and Business.” All bibliometric indicators are based on the Web of Science (WoS) volume year in order to avoid the problem that the last available year (in our case 2007) is incomplete because of delayed indexing. ${ }^{11}$ A year therefore means WoS volume year, not publication year. This makes annual publication/citation counts more stable. The counts are whole, meaning that an article with authors at two institutions is counted twice while an article with two authors at the same institution is counted once. Furthermore, the counts are based on a select list of journals covered by the Web of Knowledge and do not include publications in other journals or in book chapters, reports, books or monographs. ${ }^{12}$

An advantage of using institutional publication data is that it is not based on department productivity, but rather institutional productivity in the field of economics and business. This circumvents the issue that some institutions such as Cornell have faculty doing research in

\footnotetext{
${ }^{10}$ Specialized institutions such as engineering schools and religious institutions were also excluded. Institutional data from the Integrated Postsecondary Education Data System (IPEDS) and college websites were reviewed to determine the final list of institutions.

${ }^{11}$ This delay can cause publications to be undercounted by 10 to $20 \%$.

${ }^{12}$ For more on journals in economics and business that are included, see http://science.thomsonreuters.com/ [accessed 22 August 2011].
} 
economics who are housed in a variety of units. Also, in some institutions economists are located in the business school, in others, in arts and sciences, and sometimes even in both. With the institution as the unit of analysis, specific location does not matter. One drawback to the method used here is that counted publications are limited to those classified in economics and business by Glanzel \& Schubert (2003). So, for example, if an economist publishes in Science, it is not counted here. Another is that economists may choose different publication types and venues depending on their tier. For instance, Hartley \& Robinson (1997) suggest that liberal arts faculty may choose more interdisciplinary journals, and may more often publish monographs and textbooks as compared to their $\mathrm{PhD}$ counterparts. To the extent that this pattern holds, the data examined here may understate the publishing activity of liberal arts faculty.

We also collected whole count data for top publications defined in terms of the journal in which the article appears. Top journals for economics and business represent the top 5\% of journals in that subfield based on citation impact in a three-year citation window, averaged over the entire period. While other methods of identifying top publications have been employed, as discussed earlier, Wall (2009) finds that alternative measures result in the identification of virtually the same set of top journals. Over the period studied, academic journals have proliferated in both economics and business. The database used to count publications reflects this trend. The advantage of the "top publication” measure is that it arguably disentangles quantity from quality: To what extent are non-elite institutions gaining not only in terms of total publications (of varying quality), but in terms of top publications? 


\section{Categorization of Institutions by Tier}

The analysis requires categorization of the 771 institutions defined above into distinct tiers. Here we use a six-part categorization scheme (Top Economics PhD, Mid-PhD, Rest-PhD, Terminal Master’s Level Economics, ${ }^{13}$ Select Liberal Arts, and Other (Comprehensive Institutions)) and perform substantial sensitivity testing regarding the $\mathrm{PhD}$ groupings. The categorization scheme is based on Economics programs, but as noted earlier, the publication data include economics and business journals, venues for both economics and business faculty (and, of course, some economists are located in business schools). Thus, sensitivity testing is also conducted regarding overlap of rankings of Economics and Business programs.

Rankings of Economics PhD Programs--The main analysis categorizes economics $\mathrm{PhD}$ institutions into 3 tiers, Top-PhD, Mid-PhD, and Rest-PhD. These assignments are based on 2009 rankings of Economics PhD programs from US News and World Report and confirmed against programs listed on the American Economic Association (AEA) website (AEA, 2010). The institutions studied here were compared with 2010 NRC rankings (subsequently revised in April 2011), earlier 1995 NRC rankings, and other published lists. ${ }^{14}$

As identified in the literature review, rankings of the top group obtained from surveys and based on publication counts (using various approaches) are very highly correlated. Also, it is important to keep in mind that the analysis focuses on broad groupings of institutions, not specific rankings (e.g. $7^{\text {th }}$ or $9^{\text {th }}$ ). US News and World Report provides a single ranking of each

\footnotetext{
${ }^{13}$ The set of Terminal Master's programs in economics identified here are those that offer a Master's as the highest degree.

${ }^{14}$ NRC rankings were initially released in Fall 2010. A revision was released on 29 April 2011. All NRC 2010 figures discussed throughout this paper are based on the revised data. See NRC website http://www.nap.edu/rdp/ [Last accessed 30 June 2011].
} 
program for 55 institutions; other institutions listed are unranked. In the analysis here, the top 30 from this list are referred to as Top-PhD and the next 25 as Mid-PhD. The AEA web site (2010) identified a total of $136 \mathrm{PhD}$ programs; 135 institutions are included here. ${ }^{15}$ In the instances in which the AEA identified PhD programs not listed or ranked, these institutions were assigned to the tier called Rest-PhD institutions. There are 80 such institutions. Appendix Table 1 indicates the specific set of institutions assigned to each tier.

The Appendix also provides a detailed discussion regarding sensitivity testing of the rankings of economics programs by US News and World Report with several others. To summarize, the overlap between the top 30 institutions in the 2009 US News list and 2010 NRC (regression-weighted rankings) list is 97\% and the overlap between the 2009 US News list and 1995 National Research Council ranking based on faculty research quality is 83\%. These findings are consistent with earlier literature that points to very little change in the set of PhD programs identified in the top grouping over long periods of time. ${ }^{16}$

As in the case of studies on income inequality, it is instructive to look not only at the top institutions, but those that are consistently ranked highest in this group. Although there is some debate regarding which institutions belong to this group (and there is movement in the rankings at the very top over time, albeit small), the key objective here is to track a specific set of schools that have tended to be among the most highly ranked over time. Based on a review of rankings from the 2010 NRC, 1995 NRC, 2009 US News \& World Report, and Amir \& Knauff (2008), in Table 1 we provide separate analysis for 7 selected elite institutions (from the top 30, in no

\footnotetext{
${ }^{15}$ The set of $\mathrm{PhD}$ institutions examined here differs from the AEA list as follows: Vanderbilt (with two PhD programs) is included as one institution in our analysis; and we include Drexel which, per its website, has a PhD program. University of New Orleans, which has a PhD program, is not included in our data set due to data issues. ${ }^{16}$ Amir \& Knauff (2008) point to some programs that have made dramatic gains, but change is the exception rather than rule.
} 
specific order): MIT, Harvard, Stanford, Princeton, Chicago, Yale, and UC-Berkeley. ${ }^{17}$

Non-PhD Tiers--Terminal Master's Institutions in Economics were identified based on information provided on the website of the AEA (AEA, 2010). The AEA identified 74 such programs in 2010, 70 of which are included as Master’s here (see Appendix Table 1). ${ }^{18}$ Select liberal arts institutions in economics were identified based on Bodenhorn (2003), Table 1. His list indicates 51 such institutions based on rankings from US News \& World Report 2000. In a study of 161 liberal arts institutions, Hartley \& Robinson (1997) identified a similar set of research-active institutions. Since the focus of this study is on publishing productivity, the remaining more teaching-oriented liberal arts institutions are omitted from the analysis. Finally, the “Other” category includes all institutions classified by Carnegie 1994 as "Comprehensive” (codes 21, 22) that are not otherwise included in the categorization scheme. There are 515 such institutions. A list of the tiers, the number in each, and descriptive publication statistics are provided in Table 1.

\section{$\underline{\text { Inequality Measures }}$}

An important part of the analysis focuses on the degree to which the distribution of publishing productivity, in terms of quantity and quality, has changed over time. ${ }^{19}$ Here we

\footnotetext{
${ }^{17}$ These institutions are included in the majority, but not all of the lists examined. For instance, in the Kalaitzidakis et al. (2003) ranking, Northwestern and University of Pennsylvania are included in the top 7 in lieu of Stanford and UC-Berkeley. In the NRC 2010 ranking examined here, NYU is in the top 7 in lieu of Yale. In their overall productivity score, Grijalva and Nowell (2008) include Michigan and NYU in the top 7 in lieu of Stanford and Chicago.

${ }^{18}$ While Trinity College and Williams College are included among Master's institutions on the AEA list, the decision was made to retain them in the set of 51 liberal arts institutions analyzed here. Our data set does not have full data for two other schools included in the AEA list, Miami University $(\mathrm{OH})$ and Johns Hopkins-DC, so these schools are not included.

${ }^{19}$ Some prior research has used the Herfindahl-Hirschman Index (HHI), a measure of concentration often used in the industrial organization literature. In the case in which the number of institutions does not change over time, as is the
} 
examine several measures of inequality often-cited in the literature: the Gini Coefficient, the Coefficient of Variation (CV), and GE(2), a member of the generalized entropy index (GE) family (for definitions, see Shorrocks, 1980).

The measures examined all possess certain desirable features: they are invariant to scale and meet the Pigou-Dalton Transfer principle. In the more well-known case of income inequality, these properties mean, respectively, that a doubling of household income leaves the inequality measure unchanged, and a transfer of income from a higher to lower income household leads to a reduction in measured inequality. In the analysis here, publications stand in for income and institutions stand in for households. The Gini coefficient ranges between 0 (no inequality) to 1 (perfect inequality). The CV ranges between 0 (no inequality) and infinity. The GE measures also show greater inequality as the metric increases. A particular advantage of a GE measure is that it can be used to decompose income inequailty (or, analogously publishing inequality) into within-group (within institutional tier) inequality and between-group (between institutional tier) inequality. The GE measure analyzed here is GE(2) rather than the better known Theil Index (GE(1)) because many institutions have zero publications in a given year, making it impossible to compute the Theil Index. ${ }^{20} \mathrm{GE}(2)$ is equivalent to $1 / 2$ times the squared value of the $\mathrm{CV}$.

\section{Findings}

case here, both the HHI and the inequality measures examined here register a reduction in inequality if non-elite institutions increase their share of total publishing. In the case of industrial concentration, concentration ratios such as the HHI are preferred because they account for both the number of firms (instiututions here) and inequality. Since the number of institutions is unchanged in this analysis, inequality measures provide full information. Also, the inequality measure examined here can be decomposed, as described in the text.

${ }^{20}$ Specifically, the Theil formula takes the log of Y (where Y is income, or number of publications) and the log of zero is undefined. The GE(2) formula does not use logs. The STATA program INEQDEC0 (written by Stephen P. Jenkins, revised 24 February 2010) was used to produce the inequality results, including the decomposition. 


\section{$\underline{\text { Overview }}$}

Table 1 and Figure 1 summarize differences in publishing productivity across tiers and provide information on trends. The single most striking finding, to be expected based on faculty size alone, is the high level of publishing productivity at Top- $\mathrm{PhD}$ institutions. For the most recent period studied, 2006-07, the top $30 \mathrm{PhD}$ institutions constituted just $4 \%$ of the total sample but accounted for 36\% of total publications and 56\% of all top publications. On average, these institutions produced 108 articles per year. Furthermore, as Table 1 shows, 7 elite institutions (1\% of the total sample) from this group contributed $11 \%$ of all publications and 23\% of top publications (top 5\% most cited journals). Their average productivity was 138 articles for the period 2006-07.

The next tier-Mid-PhD—is a good distance behind, with an average of just 66 articles per year; Rest-PhD programs produced an average of 28 articles per year. The figure for Master's institutions was just 11.5 articles per year. Rounding out the set of institutions studied, Table 1 provides statistics on publishing productivity at 51 Select Liberal Arts institutions. The average annual rate at these institutions was 2-3 papers per year. Publishing productivity at these institutions is discussed in more detail shortly.

Despite considerable differences in publishing productivity across tiers, all tiers have experienced a common trend: a dramatic growth in publishing productivity from the 1990s to 2007 which can be seen in Figure 1 and in Table 2. Over the period $1994-96^{21}$ to 2006-7, publications increased by as much as 28-39\% for Top-PhD, Mid-PhD, Rest-PhD, Master's, and

\footnotetext{
${ }^{21} 1994-96$ is used as the starting year because mean publications for the elite 7 institutions were 150.4 for 19911993, but 117 for the next three time periods, suggesting that the first time period was anomalous. (The means for the other tiers increased steadily from 1991-93 to 2006-07, as shown in Table 2.)
} 
Select Liberal Arts institutions. In fact, productivity even increased among “Other” institutions (21\%), the tier which produces the lowest average annual research output.

Figure 2 focuses on publishing productivity at $\mathrm{PhD}$ institutions, highlighting the similarities and differences in productivity across tiers at various points in the publication distribution for the year 2007. Differences in productivity by tier are most pronounced at the 90th percentile, where the publication count is 172 for Top- $\mathrm{PhD}, 108$ for Mid-PhD and 49 for Rest-PhD. Nonetheless, the publication distributions across all three tiers overlap to some extent. For instance, the number of publications for Top-PhD institutions (102) at the $50^{\text {th }}$ percentile is very close to the number of publications for the top $90^{\text {th }}$ percentile of Mid-PhD institutions (108). Also, the publication count at the $10^{\text {th }}$ percentile for Top-PhD and Mid-PhD (38-42) overlaps with the publication count at the $80^{\text {th }}$ and $90^{\text {th }}$ percentiles for Rest-PhD (41-49).

Figure 3 next compares the distributions of publications at Rest-PhD and Master's Level institutions for 2007. While, as noted, average annual publishing productivity was more than twice as large at Rest-PhD versus Master's institutions (28 versus 11.5 publications per year), the publication distributions overlap substantially. The number of publications produced at the $60^{\text {th }}$ percentile and higher by Master's institutions (12-26) is similar to the number of publications produced by the $10^{\text {th }}-40^{\text {th }}$ percentiles for Rest-PhD (10-23). Taken together, Figures 2 and 3 illustrate the point that data on average publishing productivity mask considerable variation in research productivity by academics located within these tiers.

The remainder of this section examines publishing productivity at liberal arts institutions. Several caveats must be kept in mind in comparing publication rates at these institutions with other tiers. First, by definition, liberal arts schools tend to be more teaching-oriented. Second, it 
has been suggested that liberal arts faculty tend to publish in somewhat different venues, more often publishing interdisciplinary work along with chapters in books, monographs, and textbooks (Hartley \& Robinson, 2007). And third, most noteworthy, research productivity is highly correlated with faculty size. ${ }^{22}$ Liberal arts institutions, for the most part, do not have graduate programs, and do not have business schools. Thus, they will likely have fewer publications in business (finance, accounting, management, etc.) outlets as well as fewer faculty members.

Table 3 sheds light on differences in average and median faculty size for selected tiers using data made available by The Committee on the Status of Women in the Economics Profession (CSWEP). ${ }^{23}$ The advantage of these data is that they provide information for a consistent definition of faculty over time. Faculty is defined as tenure-track or tenured economic department faculty members holding the rank of assistant, associate or full professor. CSWEP provides information on 29-35 of the liberal arts institutions studied here for the years 2001, 2003, and 2007, and 69-102 PhD institutions for the selected subperiods from 1993-2007. One limitation of the CSWEP data on faculty size is that they are at the department level, not at the institution level, and consequently these figures understate the full set of faculty publishing in economics and business (e.g. faculty located in business schools). ${ }^{24}$ The CSWEP data indicate a difference in faculty size of 3:1 for PhD versus liberal arts institutions. Unquestionably, this

\footnotetext{
${ }^{22}$ In the case of $\mathrm{PhD}$ institutions, faculty size is directly linked to the size of the $\mathrm{PhD}$ cohort. Indeed, Becker, Green, and Siegfried (2011) find that the key explanatory factor is the average expected size of the PhD student cohort, with an additional faculty member added for each additional increase in long-term cohort size. In contrast, at Bachelor's only institutions, faculty size is determined by the expected long-term number of undergraduate students, with one faculty member added for each long-term addition of 10 graduating majors.

${ }^{23}$ The authors gratefully acknowledge data provided by CSWEP, drawn from their annual surveys, 1993 - 2010, on faculty size for economics departments and percent female.

${ }^{24}$ Counting of faculty is also made difficult by the fact that some ranked faculty hold positions in both economics and business programs, and some economists are located in other programs entirely (public policy, consumer economics, schools of labor and industrial relations, etc.)
} 
difference is even larger when faculty in business schools and other research units at $\mathrm{PhD}$ institutions are included. ${ }^{25}$

Within the set of Select Liberal Arts institutions, researchers (Hartley \& Robinson, 1997; Bodenhorn, 1997, 2003) have observed that a small set of institutions produce the majority of the research. Table 4 revisits this finding, comparing average publishing productivity for all of the 51 Select Liberal Arts institutions (same set as Table 1) with the most research-active of this tier: the top ten institutions that produced the most papers published in economics and business in each of six selected subperiods, spanning the period 1991-2007. While the full set of Select Liberal Arts institutions produced 2-3 papers per year, the average output of the top ten (the set varies somewhat for each year) was closer to 5-7 publications per year. Further, the top ten institutions contributed about 50 percent of the total publications for this tier as measured by publication counts in economics and business in Web of Knowledge. ${ }^{26}$ The schools most frequently included among the top ten for the 6 subperiods are: Williams, Wesleyan, Wellesley, Middlebury, Barnard, Claremont-McKenna and Swarthmore. ${ }^{27}$ Another 13 institutions are included among the top ten most research active in at least one of the 6 subperiods studied. ${ }^{28}$ Notably, our study identifies virtually the same set of institutions as Bodenhorn $(1997,2003)$ and

\footnotetext{
${ }^{25}$ Another trend, shown in Table 3, is that women's share of ranked faculty has increased over the period of study though women continue to remain extremely underrepresented among ranked faculty at Top-PhD institutions (and even at any other $\mathrm{PhD}$ institution). Regrettably, the data do not permit us to examine the relationship between the changing gender composition of ranked faculty and changes in publishing productivity within and across tiers.

${ }^{26}$ For the early 1990s, Hartley \& Robinson (1997) find that 20 schools published the top 50\% of papers. The figures are not fully comparable because the underlying set of journals differs (their dataset is the Journal of Economic Literature(JEL) now EconLit).

${ }^{27}$ The average faculty size of these institutions is around 16 , as compared to 10 for a broader set of select liberal arts institutions as reported in Table 3. This is consistent with the prior literature, including Bodenhorn (2003), which shows that larger faculties produce more output.

${ }^{28}$ These institutions are (in no particular order): Amherst, Hamilton, Lafayette, Bucknell, Colgate, Washington \& Lee, Trinity, Colby, Union, Oberlin, Skidmore, Bowdoin, and College of Holy Cross.
} 
Hartley \& Robinson (1997), despite differences in what output measure is being ranked (e.g. citations, quality-adjusted articles) and time period.

Trends in Publishing Inequality

Tables 5 and 6 focus on the degree of inequality across tiers, as well as how the extent of inequality has changed over time. Specifically, to what extent has inequality declined, as would be expected based on the effect of the IT revolution and increased research expectations at nonelite institutions? Table 5 shows trends in inequality for all institutions, and by tier, as measured by the Gini and CV. In separate work, we investigated whether the trend is statistically significant at the $5 \%$ level; this information is indicated in the table by an asterisk. ${ }^{29}$

Both inequality measures examined here indicate a slight reduction in overall inequality (all tiers combined), with the Gini falling from .83 to .81 and the CV falling from 2.41 to 2.27. These declines, although small, are statistically significant at the 5\% level and provide evidence of "nibbling." Next, we look at trends within tiers. Notably, the greatest decline occurs for the Rest-PhD tier, with a decline in the Gini from .37 to .33 and a decline in the CV from .68 to .60, again both statistically significant trends. Statistically significant declines in inequality are also found for Master's and for Other (Gini measure only). Interestingly, there is no evidence of a statistically significant change in measured inequality for Select Liberal Arts institutions.

The left hand side of Table 6 more fully investigates the decline in overall inequality (all tiers taken together) in total publications, by decomposing the change into two parts: the part due to changes in inequality within tiers and the part due to changes in inequality between tiers. The

\footnotetext{
${ }^{29}$ We estimated each inequality series as a function of a time trend and constant for the 17-year period from 19912007.
} 
measure analyzed is GE(2), discussed earlier, which is computed using the CV (from Table 5), and is calculated as $1 / 2 \mathrm{CV}$ squared. Before discussing trends in the series, it is instructive to note that regardless of whatever year is examined, between-tier inequality is the largest component of total inequality (nearly 3/4ths). This finding is to be expected since factors underlying research productivity (research expectations, faculty size, and resources) differ significantly by tier.

As was found for the CV and Gini, we identify a statistically significant decline in overall inequality in total publications using GE(2) from 2.91 to 2.58. Notably, the decomposition results in Table 6 point to a significantly significant decline in between-tier inequality over the period 1991-2007 (indicated in the table by an asterisk), evidence of nibbling, though an insignificant trend for within-tier inequality.

The righthand side of Table 6 also provides evidence on inequality for top publications. Before focusing on trends, it is quite striking that the value of GE (2) for overall inequality in 2007, 6.31, is substantially higher for top publications as compared to just 2.58 for all publications. This reflects the fact, highlighted in Tables 1 and 2, that only a very small fraction of institutions (principally Top-PhD and to some extent, Mid-PhD) produce publications in the most highly cited journals. Returning to the main focus, trends in inequality, the analysis indicates no statistically trend in inequality for top publications from 1991-2007, in contrast to significant declines in measured inequality for all publications over the same period.

\section{Changing Ratios of Mean Publications by Tier}

Table 7 provides further evidence on the extent to which less elite institutions are nibbling at their more elite counterparts in terms of total and top publications produced. This 
table shows the ratio of mean publications for the various tiers and reports whether the identified trends from 1991-2007 are statistically significant (as indicated by an asterisk in the table). For instance, column 2 shows that the ratio of mean publications at Mid-PhD institutions to RestPhD institutions declined from 2.58 to 2.34 . Separate analysis indicates this trend is statistically significant at the $5 \%$ level. Also, a statistically significant decline is found for Top-PhD/RestPhD publications. These ratios indicate rising relative research productivity at less-elite $\mathrm{PhD}$ granting institutions. What is perhaps most striking is that when the quality of research is controlled for, the level of relative quality at Mid-PhD institutions compared to Rest-PhD institutions decreased as well (Panel B of Table 7). Specifically, top publications for MidPhD/Rest-PhD fell from 4.09 to 3.36, a statistically significant decline. ${ }^{30}$ Nonetheless, the results in Table 7 and the modest declines identified in measured inequality in Tables 5 and 6 , albeit statistically significant, suggest that considerable concentration remains the dominant story, especially for “top” publications.

\section{Conclusion}

This study analyzed publishing productivity in economics and business for 771 colleges and universities for the 17-year period from 1991-2007. Several findings emerge. First, across all tiers, publishing productivity has increased. This general rise, regardless of tier, is consistent with the proliferation of journals. It is also consistent with a continuing increased emphasis on publication. Second, consistent with the "democratization” effects of IT as well as increased research expectations of less elite institutions, publishing inequality has declined from a

\footnotetext{
${ }^{30}$ This analysis was replicated using the PhD categorizations from the NRC 2010 rankings. This analysis also shows statistically significant gains made in terms of quantity and quality of publishing for Rest PhD relative to their more elite $\mathrm{PhD}$ peers.
} 
statistical standpoint, though the magnitude of the change is very small. Also, consistent with observed evidence of a decline in publishing inequality is some evidence that lower-ranked economics $\mathrm{PhD}$ institutions are gaining in both quantity and quality-adjusted counts of publications relative to their more elite peers. Again, however, in terms of magnitude these gains are small. Thus, the story is more one of constancy than one of change, even in the face of changing technology and rising research expectations. The fact remains that the most elite $\mathrm{PhD}$ programs are far larger in size and possess many more resources than do programs at other institutions.

While some evidence of a statistically significant decline in inequality was also found among Master's and Other institutions, this was not the case among Select Liberal Arts institutions. Here it appears that a small group of these institutions continue to dominate publishing productivity as measured by publication counts from the Web of Knowledge.

This study has focused on research articles published in traditional venues—refereed, and for the most part, print journals. Looking forward, the IT revolution is changing the publishing landscape, not just by creating access to virtual research, data, and colleagues for those at lesselite institutions, as emphasized here, but it may also threaten the traditional peer-review process (Ellison, 2011). As the time from submission to acceptance has grown tremendously at top journals (Ellison 2002), the Internet provides electronic alternatives for dissemination, from papers made available on personal web pages to electronic paper series. In Ellison's (2011) study of researchers at top economics departments and Harvard in particular, he identifies a shift away from publishing in traditional peer-reviewed journals, consistent with changes in technology and the slowdown in the publishing process. Most relevant to the paper at hand, are 
the long-term implications of this trend for researchers located at less high-profile institutions. IT may shift from having a potentially democratizing role on publishing productivity, to one that exacerbates differences by author's institutional affiliation; economists at less elite institutions will need to continue to rely on the peer-review process for "validation" of the quality of work, while this process may become less important for those at top institutions. To investigate this pattern, future research will need to systematically look at measures of publishing output and citations that go beyond peer-reviewed publications for a broad set of institutions. 


\section{Bibliography}

Agrawal, A. \& A. Goldfarb. 2008. Restructuring Research: Communication Costs and the Democratization of University Innovation. American Economic Review 98(4): 1578-1590.

American Economic Association. www.vanderbilt.edu/AEA/gradstudents/schools.htm, accessed July 2010.

Amir, R. \& M. Knauff. 2008. Ranking Economics Departments Worldwide on the Basis of PhD Placement. Review of Economics and Statistics 90(1): 185-190.

Barbezat, D.A. Gender Differences in Research Patterns Among PhD Economists, Journal of Economic Education, 37(3):359-375.

Becker, Jr., W.E., W.H. Greene \& J.J. Siegfried. 2011. Do Undergraduate Majors or PhD Students Affect Faculty Size? American Economist 56(1): 69-77.

Bodenhorn, H. 1997. Teachers, and Scholars Too: Economic Scholarship at Elite Liberal Arts Colleges. Journal of Economic Education 28(4):323-336.

Bodenhorn, H. 2003. Economic Scholarship at Elite Liberal Arts Colleges: A Citation Analysis with Rankings. Journal of Economic Education 34(4): 341-359.

Braun, T., W. Glanzel, A. Schubert. 2006. A Hirsch-Type Index for Journals. Scientometrics 69(1): 169-73.

Butler, D.M., R.J. Butler \& J.T. Rich. 2008. The Equalizing Effect of the Internet on Access to Research Expertise in Political Science and Economics. PS-Political Science \& Politics 41(3): 579-584.

Cardoso, A.R., P. Guimaraes and K.F. Zimmerman. 2010. Trends in Economic Research: An International Perspective. KYKLOS 63(4): 479-494.

Carnegie Foundation for the Advancement of Teaching. 1994. A Classification of Institutions of Higher Education-1994 Edition. Princeton, NJ: The Carnegie Foundation for the Advancement of Teaching.

Cohen, J. 1996. Computer Mediated Communication and Publication Productivity Among Faculty. Internet Research 6(2-3): 41-63. 
Coupé, T. 2003. Revealed Performances: Worldwide Rankings of Economists and Economics Departments, 1969-2000. Journal of the European Economic Association 1 (6): 1309-1345.

Coupé, T. 2004. What Do We Know About Ourselves? On the Economics of Economics. KYKLOS 57(2): 197-216.

Ding, W.W., S.G. Levin, P.E. Stephan \& A.E. Winkler. 2010. The Impact of Information Technology on Academic Scientists' Productivity and Collaboration Patterns. Management Science 56(9): 1439-1461.

Dusansky, R. \& C.J. Vernon. 1998. Rankings of U.S. Economics Departments. Journal of Economic Perspectives 12(1): 157-170.

Ellison G. 2002. The Slowdown of the Economics Publishing Process. Journal of Political Economy 110(5): 947-993.

Ellison, G. 2011. Is Peer Review in Decline? Economic Inquiry 49(3): 635-657.

Engemann, K.M. \& H.J. Wall. 2009. A Journal Ranking for the Ambitious Economist. Federal Reserve Bank of St. Louis Review (May/June).

Franzoni, C., G. Scellato and P. Stephan, 2011. “Changing Incentives to Publish.” Science 33:702-703.

Glänzel, W. \& A. Schubert. 2003. A New Classification Scheme of Science Fields and Subfields Designed for Scientometric Evaluation Purposes. Scientometrics 56 (3): 357-367.

Graber, M., A. Launov, \& K. Walde. 2008. Publish or Perish? The Increasing Importance of Publications for Prospective Economics Professors in Austria, Germany and Switzerland. German Economic Review 9(4): 457-472.

Grijalva, T. C. \& C. Nowell. 2008. A Guide to Graduate Study in Economics: Ranking Economics Departments by Fields of Expertise. Southern Economic Journal 74(4): 971-996.

Hamermesh, D. 1989. Why Do Individual-Effects Models Perform so Poorly? The Case of Academic Salaries. Southern Economic Journal 56: 39-45.

Hamermesh, D. \& S. Oster. 2002. Tools or Toys? The Impact of High Technology on Scholarly Productivity. Economic Inquiry 40 (4): 539-555.

Harter, C.L., W.E. Becker and M. Watts. 2004. Changing Incentives and Time Allocation for Academic Economists: Results from 1995 and 2000 National Surveys. Journal of Economic Education 35(1):89-97. 
Hartley, J.E. \& M.D. Robinson. 1997. Economic Research at National Liberal Arts Colleges: School Rankings. Journal of Economic Education 28(4): 337-349.

Hesse, B.W., L.S. Sproull, S.B. Kiesler \& J.P. Walsh. 1993. Returns to Science-Computernetworks in Oceanography. Comm. ACM 36(8): 90-101.

Hirsch, J. 2005. An Index to Quantify an Individual's Scientific Research Output. Proceedings of the National Academy of Sciences 102(46): 16569-72.

Hodgson, G.M. \& H. Rothman. 1999. The Editors and Authors of Economics Journals: A Case of Institutional Oligopoly? Economic Journal 109(2): F165-86.

Jenkins, S. P. 2010. INEQDEC0: State Module to Calculate Inequality Indices with Decomposition by Subgroup. Statistical Software Components S366007, Boston College Department of Economics (1999; revised 24 Feb 2010).

Kalaitzidakis, P., T.P. Mamuneas \& T. 2003. Rankings of Academic Journals and Institutions in Economics. Journal of the European Economic Association 1: 1346-1366.

Kim E. H., A. Morse \& L. Zingales. 2009. Are Elite Universities Losing Their Competitive Edge? Journal of Financial Economics 93(3): 353-381.

Kocher, M.G. \& M. Sutter. 2001. The Institutional Concentration of Authors in Top Journals of Economics During the Last Two Decades. Economic Journal 111(472): 405-422.

Laband, D.N. \& R.D. Tollison. 2003. Dry Holes in Economic Research. Kyklos 56(2): 161-174.

Levin, S. G., P. E. Stephan \& A. E. Winkler. 2011. Innovation in Academe: The Diffusion of Internet Technologies. Applied Economics on-line: 1-18.

Long, S. 1978. Productivity and Academic Position in the Scientific Career. American Sociological Review 43(6): 889-908.

Mayer, T. 2004. Dry Holes in Economic Research: Comment. KYKLOS 57(4): 621-626.

McCoy, J.P. and M.I. Milkman. 2006. Evolution of the Master's in Economics. Journal of Economic Education 37(4):470-476.

National Research Council. 1995. Research-Doctorate Programs in the United States (National Research Council Press: Washington, DC).

Ragan, J., J. Warren \& B. Bratsberg, 1999. How Similar are Pay Structures in 'Similar' Departments of Economics? Economics of Education Review 18: 347-360.

Oyer, P. 2006. Initial Labor Market Conditions and Long-Term Outcomes for Economists. Journal of Economic Perspectives 20 (3):143-160. 
Scott, L.C. \& P.M. Mitias. 1996. Trends in Rankings of Economics Departments in the U.S.: An Update. Economic Inquiry, 34(2): 378-400.

Shorrocks, A. F. 1980. The Class of Additively Decomposable Inequality Measures. Econometrica 48 (3): 613-625.

Stephan P. \& S. Levin. 1992. Striking the Mother Lode in Science: The Importance of Age, Place and Time. New York: Oxford University Press.

Stephan, P. E. 2010. The Economics of Science. In B. H. Hall \& N. Rosenberg, editors, Handbook of Economics and Innovation, Vol. 1, pp. 217-274, Elsevier.

Tracy J. \& J. Waldfogel. 1997. The Best Business Schools: A Market-Based Approach. Journal of Business 70(1): 1-31.

Thursby, J.G. 2000. What Do We Say About Ourselves and What Does It Mean? Yet Another Look at Economics Department Research. Journal of Economic Literature, 38(2):3 83-404.

US News and World Report, Best Graduate Schools, Economics, Ranked in 2009. (http://gradschools.usnews.rankingsandreviews.com/best-graduate-schools/top-economics-schools/rankings. Accessed July 2010).

Wall, H. J. 2009. Journal Rankings in Economics: Handle with Care. Working Paper 2009014A, Federal Reserve Bank of St. Louis.

Whitman, M.E., A.R. Hendrickson \& A.M. Townsend. 1999. Research Commentary. Academic Rewards for Teaching and Service: Data and Discourse. Information Systems Research 10(2): 99-109.

Winkler, A.E., Glanzel W., Levin S.G., \& Stephan, P.E. (2011.). The Diffusion of Information Technology and the Increased Propensity of Teams to Transcend Institutional and National Borders. Working Paper.

Wu, S. 2005. Where Do Faculty Receive Their PhDs: A Comparison Across Six Disciplines. Academe 91(4). (http://www.aaup.org/AAUP/pubsres/academe/2005/JA/Feat/wu.htm)

Zivney, T.L. \& W.J. Bertin. 1992. Publish or Perish: The Competition is Really Doing. Journal of Finance 47(1): 295-329.

Zuckerman, H., J.R. Cole \& J.T. Bruer. 1991. The Outer Circle: Women in the Scientific Community. New York and London: Norton. 
Appendix: Sensitivity Testing of Institutions included in PhD Tiers

As discussed in the text, 2009 U.S. News and World Report rankings were used to construct the set of institutions included in the Top-PhD, Mid-PhD, and Rest-PhD tiers. The specific institutions included in each tier are listed in Appendix Table 1. For purposes of sensitivity testing, we compared the US News list with other rankings.

First, we looked at findings from the National Resource Council. The National Resource Council reported new rankings in Fall 2010 (subsequently revised in April 2011) based on data collected during 2005-2006 (National Academies Press website). Only the revised 2010 rankings are reported here, referred to as 2010 NRC rankings. These rankings update earlier rankings reported in 1995, which were based on data collected in 1993 (referred to as 1995 NRC rankings here). The NRC made a major change in its methodology from 1995 to 2010; for 2010 it reports rankings using a range $\left(5^{\text {th }}\right.$ and $95^{\text {th }}$ percentile rankings) rather than reporting a single numerical score. This change was made to reflect the inherent difficulties and questions about meaningfulness in precisely ordering PhD programs. The 2010 NRC also reports two distinct rankings for users to choose from (as well giving the user the ability to change the weights assigned to each), one regression-based (R) and another survey-based (S). The rankings reported here for comparison purposes (see Appendix Table 2) were obtained using the regression-based measure (with the weight set equal to the maximum score, 5). The overlap between the top 30 institutions in the R and S-based methods (where weight is set $=5$, respectively) is $80 \%{ }^{31}$ Appendix Table 2 lists the top 30 institutions identified in the 2010 NRC ranking (R-

\footnotetext{
${ }^{31}$ The survey-based measure includes several institutions in the top 30 that are not included on any other list examined: University of Wyoming, Syracuse, Pittsburgh, and Iowa State. And, notably, it excludes UCLA.
} 
based method) alongside the top 30 institutions identified by the 2009 US News and World Report. There is a 97\% overlap between these lists. To provide more information on the extent of overlap, Appendix Table 3 provides means and descriptive statistics for Top-PhD, Mid-PhD and Rest-PhD based on groupings from the 2010 NRC. The means for each PhD grouping are very similar to those reported in Table 2, which were constructed using economics $\mathrm{PhD}$ groupings from US News.

Next, we compared the 2009 US News list of top 30 institutions with a number of other rankings. As shown in Appendix Table 2, the overlap between the 2009 US News list and Amir \& Knauff (2008) is 90\%, and the overlap between the 2009 US News list and 1995 NRC based on faculty research quality is $83 \%$. These findings are consistent with earlier literature that points to very little change in the set of $\mathrm{PhD}$ programs identified in the top grouping over long periods of time.

Finally, we compared the percentage overlap between the top 30 Economics PhD ranking from US News with the top 30 business school rankings from the same source and from Forbes (2005). ${ }^{32}$ As shown in Appendix Table 2, these overlaps are 63\% and 73\% respectively. It is also instructive to note that virtually every institution that has a $\mathrm{PhD}$ program in economics also offers a business degree of some type. Important exceptions are Cal Tech, Brown, and Princeton.

\footnotetext{
32 Tracy \& Waldfogel (1997) also produced a ranking for business schools, but its focus is on salary earned by students ("value added") rather than research quality.
} 


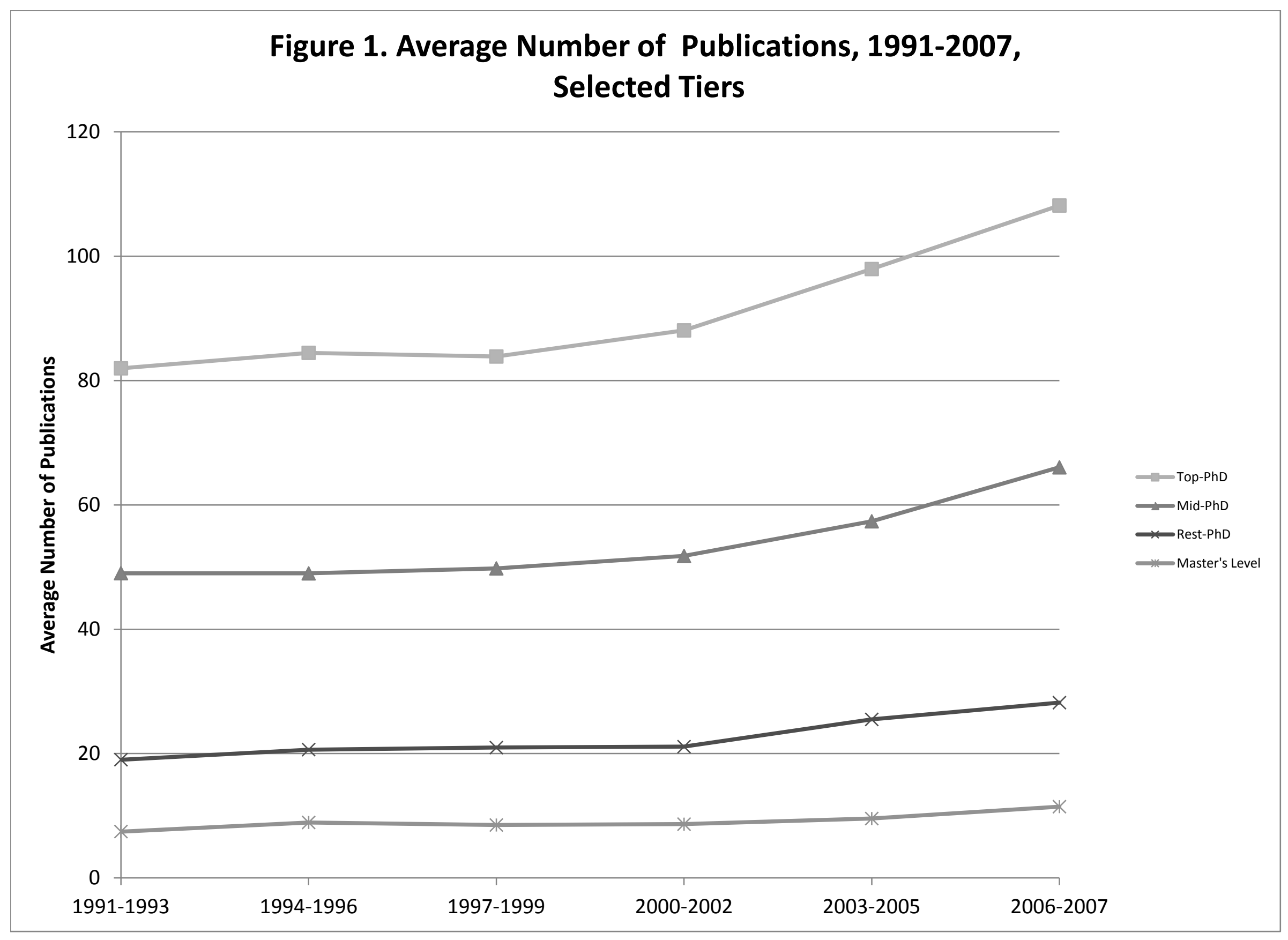

Data sourced from Thomson Reuters Web of Knowledge (formerly referred to as ISI Web of Science). 


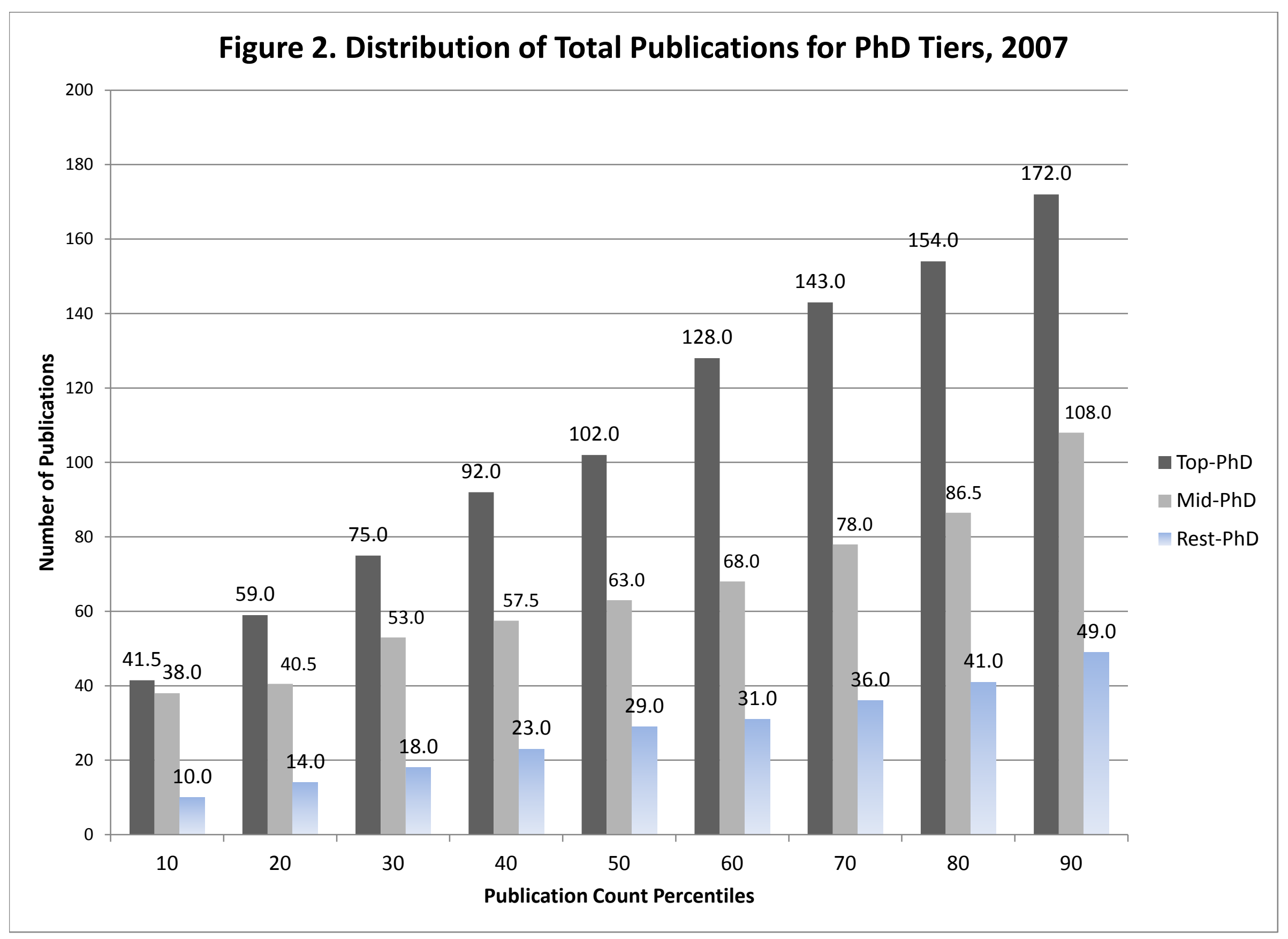

Data sourced from Thomson Reuters Web of Knowledge (formerly referred to as ISI Web of Science). 


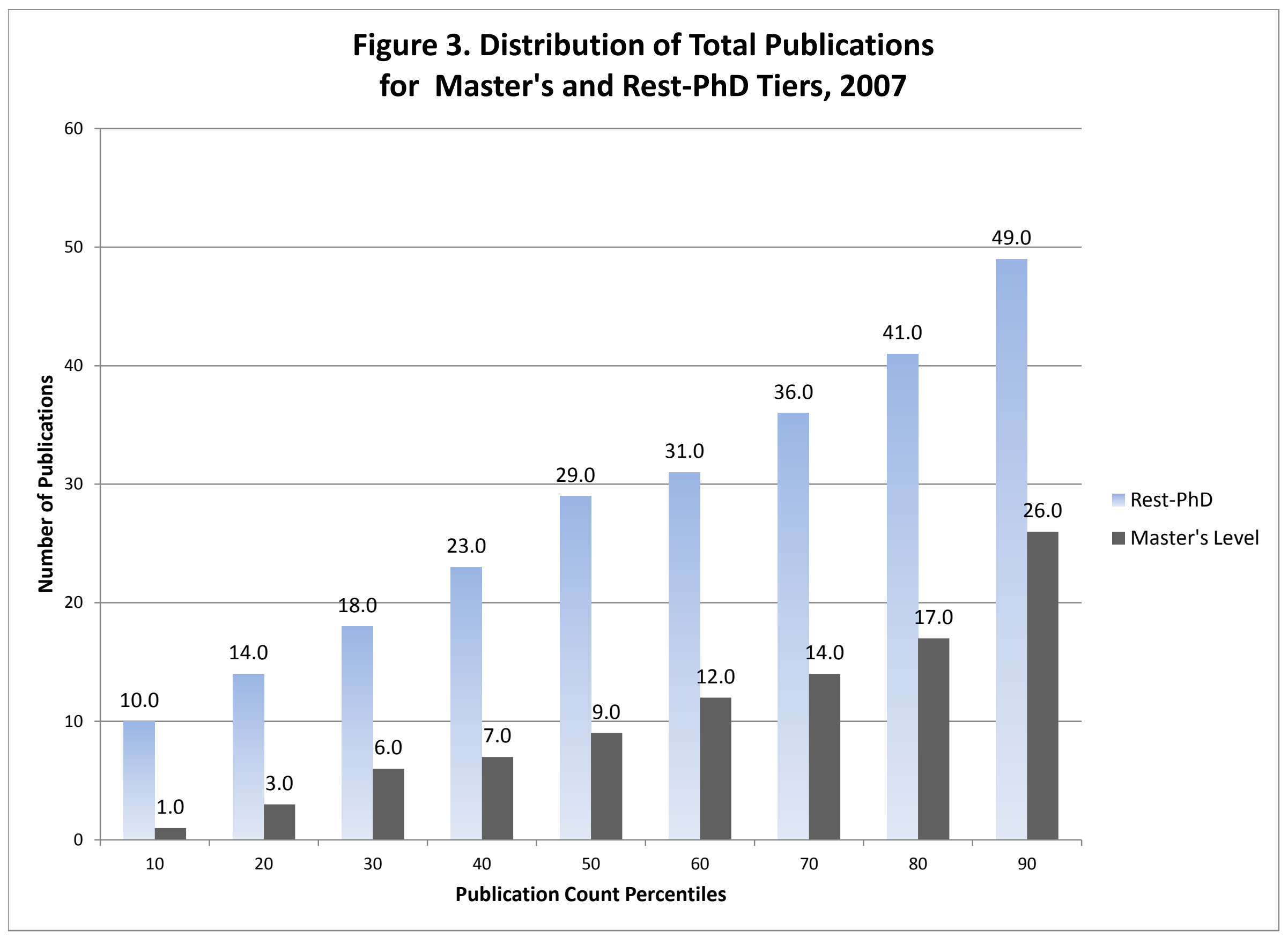

Data sourced from Thomson Reuters Web of Knowledge (formerly referred to as ISI Web of Science). 
Table 1. Summary Statistics by Tier for Selected Subperiods

\begin{tabular}{l}
$\begin{array}{l}\text { Number of } \\
\text { Institutions } \\
\text { per Tier }\end{array}$ \\
\cline { 2 - 3 }
\end{tabular}


Table 2. Descriptive Statistics by Tier and Period

\begin{tabular}{|c|c|c|c|c|c|c|c|c|c|c|c|c|}
\hline \multirow[b]{3}{*}{ Period } & \multicolumn{6}{|c|}{ Top-PhD ( $n=30$, includes selected elite) } & \multicolumn{6}{|c|}{ Mid-PhD $(n=25)$} \\
\hline & \multicolumn{4}{|c|}{ All Publications } & \multicolumn{2}{|c|}{ Top Publications } & \multicolumn{4}{|c|}{ All Publications } & \multicolumn{2}{|c|}{ Top Publications } \\
\hline & Mean & SD & Median & $\begin{array}{l}\text { Share } \\
\text { of Total }\end{array}$ & Mean & $\begin{array}{c}\text { Share of } \\
\text { Total }\end{array}$ & Mean & SD & Median & $\begin{array}{l}\text { Share } \\
\text { of Total }\end{array}$ & Mean & $\begin{array}{c}\text { Share of } \\
\text { Total }\end{array}$ \\
\hline 1991-1993 & 82.0 & 40.0 & 83.0 & 0.38 & 19.4 & 0.58 & 49.0 & 18.9 & 49.0 & 0.19 & 7.2 & 0.18 \\
\hline 1994-1996 & 84.5 & 42.7 & 80.5 & 0.36 & 18.7 & 0.57 & 49.0 & 18.3 & 47.0 & 0.18 & 7.0 & 0.18 \\
\hline 1997-1999 & 83.9 & 42.7 & 77.0 & 0.36 & 19.1 & 0.54 & 49.8 & 18.1 & 49.0 & 0.18 & 7.5 & 0.18 \\
\hline 2000-2002 & 88.1 & 45.5 & 85.5 & 0.37 & 23.0 & 0.57 & 51.8 & 17.9 & 51.0 & 0.18 & 8.4 & 0.17 \\
\hline 2003-2005 & 97.9 & 48.3 & 98.5 & 0.36 & 24.9 & 0.59 & 57.4 & 22.1 & 54.0 & 0.18 & 7.9 & 0.16 \\
\hline \multirow[t]{4}{*}{ 2006-2007 } & 108.2 & 57.0 & 102.0 & 0.36 & 24.7 & 0.56 & 66.0 & 23.7 & 62.0 & 0.18 & 9.2 & 0.17 \\
\hline & \multicolumn{6}{|c|}{ Rest-Phd $(\mathrm{n}=80)$} & \multicolumn{6}{|c|}{ Master's Institutions $(\mathrm{n}=70$ ) } \\
\hline & \multicolumn{4}{|c|}{ All Publications } & \multicolumn{2}{|c|}{ Top Publications } & \multicolumn{4}{|c|}{ All Publications } & \multicolumn{2}{|c|}{ Top Publications } \\
\hline & Mean & SD & Median & $\begin{array}{l}\text { Share } \\
\text { of Total }\end{array}$ & Mean & $\begin{array}{c}\text { Share of } \\
\text { Total }\end{array}$ & Mean & SD & Median & $\begin{array}{l}\text { Share } \\
\text { of Total }\end{array}$ & Mean & $\begin{array}{c}\text { Share of } \\
\text { Total }\end{array}$ \\
\hline 1991-1993 & 19.0 & 12.8 & 17.0 & 0.23 & 1.8 & 0.14 & 7.5 & 6.7 & 6.0 & 0.08 & 0.6 & 0.04 \\
\hline 1994-1996 & 20.6 & 12.4 & 20.0 & 0.24 & 2.0 & 0.16 & 8.9 & 7.0 & 7.5 & 0.09 & 0.5 & 0.04 \\
\hline 1997-1999 & 21.0 & 12.1 & 20.0 & 0.24 & 2.2 & 0.17 & 8.5 & 6.9 & 7.0 & 0.09 & 0.6 & 0.04 \\
\hline $2000-2002$ & 21.1 & 12.0 & 20.0 & 0.24 & 2.4 & 0.16 & 8.7 & 7.0 & 7.0 & 0.08 & 0.6 & 0.04 \\
\hline 2003-2005 & 25.5 & 14.29 & 25.0 & 0.25 & 2.5 & 0.15 & 9.6 & 8.0 & 8.0 & 0.08 & 0.7 & 0.04 \\
\hline \multirow[t]{3}{*}{ 2006-2007 } & 28.2 & 16.5 & 29.0 & 0.25 & 2.7 & 0.16 & 11.5 & 9.0 & 9.0 & 0.09 & 0.8 & 0.04 \\
\hline & \multicolumn{6}{|c|}{ Select Liberal Arts Institutions $(n=51)$} & \multicolumn{6}{|c|}{ Other Institutions $(n=515)$} \\
\hline & \multicolumn{4}{|c|}{ All Publications } & \multicolumn{2}{|c|}{ Top Publications } & \multicolumn{4}{|c|}{ All Publications } & \multicolumn{2}{|c|}{ Top Publications } \\
\hline Period & Mean & SD & Median & $\begin{array}{c}\text { Share } \\
\text { of Total }\end{array}$ & Mean & $\begin{array}{c}\text { Share of } \\
\text { Total } \\
\end{array}$ & Mean & SD & Median & $\begin{array}{l}\text { Share } \\
\text { of Total }\end{array}$ & Mean & $\begin{array}{c}\text { Share of } \\
\text { Total }\end{array}$ \\
\hline 1991-1993 & 1.9 & 2.2 & 1.0 & 0.02 & 0.2 & 0.01 & 1.3 & 3.0 & 0.0 & 0.10 & 0.1 & 0.05 \\
\hline 1994-1996 & 2.0 & 2.0 & 2.0 & 0.01 & 0.2 & 0.01 & 1.6 & 3.4 & 0.0 & 0.12 & 0.1 & 0.05 \\
\hline 1997-1999 & 2.2 & 2.2 & 2.0 & 0.02 & 0.2 & 0.01 & 1.6 & 3.4 & 0.0 & 0.12 & 0.1 & 0.06 \\
\hline 2000-2002 & 2.2 & 2.5 & 1.0 & 0.02 & 0.2 & 0.01 & 1.6 & 3.6 & 0.0 & 0.12 & 0.1 & 0.05 \\
\hline 2003-2005 & 2.7 & 3.0 & 2.0 & 0.02 & 0.2 & 0.01 & 1.8 & 4.0 & 0.0 & 0.11 & 0.1 & 0.06 \\
\hline 2006-2007 & 2.7 & 2.8 & 2.0 & 0.02 & 0.2 & 0.01 & 2.0 & 4.3 & 0.0 & 0.11 & 0.1 & 0.05 \\
\hline
\end{tabular}

Notes: Data sourced from Thomson Reuters Web of Knowledge (formerly referred to as ISI Web of Science). 
Table 3. Faculty Sizes for Selected Years and Tiers, based on Annual CSWEP Survey

\begin{tabular}{|c|c|c|c|c|}
\hline & $\begin{array}{c}\text { number of } \\
\text { institutions } \\
\text { in CSWEP survey }\end{array}$ & $\begin{array}{c}\text { Average } \\
\text { Faculty Size }\end{array}$ & $\begin{array}{l}\text { Median } \\
\text { Faculty Size }\end{array}$ & $\%$ Female \\
\hline \multicolumn{5}{|l|}{1993} \\
\hline Selected Elite PhD & 7 & 39.2 & 38 & 9.4 \\
\hline Top-PhD & 26 & 32.2 & 31 & 8.9 \\
\hline Any-PhD & 81 & 26.8 & 25 & 12.3 \\
\hline \multicolumn{5}{|l|}{2001} \\
\hline Selected Elite PhD & 7 & 40.4 & 41 & 11.7 \\
\hline Top-PhD & 22 & 36.7 & 35 & 11.1 \\
\hline Any-PhD & 69 & 25.4 & 22 & 11.9 \\
\hline Select Liberal Arts & 29 & 10.4 & 9 & 27.1 \\
\hline \multicolumn{5}{|l|}{2003} \\
\hline Selected Elite PhD & 7 & 42.5 & 41 & 10.7 \\
\hline Top-PhD & 28 & 31.4 & 31 & 12.5 \\
\hline Any-PhD & 95 & 25.0 & 23 & 14.7 \\
\hline Select Liberal Arts & 29 & 10.1 & 9 & 27.1 \\
\hline \multicolumn{5}{|l|}{2007} \\
\hline Selected Elite PhD & 7 & 44.8 & 43 & 13.7 \\
\hline Top-PhD & 29 & 35.2 & 34 & 12.7 \\
\hline Any-PhD & 102 & 24.9 & 23 & 16.0 \\
\hline Select Liberal Arts & 35 & 10.0 & 10 & 32.0 \\
\hline
\end{tabular}

Notes: Data are based on CSWEP annual survey, 1993-2007.

Faculty refers to ranked faculty (tenured-track and tenured) at the assistant, associate and full professor levels. Visiting professors are not counted.

Selected Elite PhD refers to 7 institutions per Table 1; Top-PhD refers to 30 institutions per Table 1 and Appendix Table 1. Select Liberal Arts refer to institutions identified by Bodenhorn (2003). Any-PhD refers to any institution with an economics PhD program. 
Table 4. Publishing Productivity Across 51 Select Liberal Arts Institutions

\begin{tabular}{|c|c|c|c|c|c|}
\hline 1991-93 & 1994-96 & 1997-99 & 2000-02 & 2003-05 & 2006-07 \\
\hline 1.9 & 2 & 2.2 & 2.2 & 2.7 & 2.7 \\
\hline 4.6 & 4.6 & 4.9 & 5.8 & 7.2 & 6.6 \\
\hline 0.47 & 0.46 & 0.44 & 0.52 & 0.53 & 0.48 \\
\hline
\end{tabular}

Notes: Data sourced from Thomson Reuters Web of Knowledge (formerly referred to as ISI Web of Science).

${ }^{\text {a } O v e r ~ t h e ~} 6$ subperiods analyzed, the following 7 institutions were included in the top ten for

4 - 6 subperiods: Williams, Wellesley, Wesleyan, Claremont-McKenna, Middlebury, Barnard, and Swarthmore.

Another 13 institutions were included in the top ten for 1-3 subperiods: Amherst, Hamilton,

Lafayette, Bucknell, Colgate, Washington \& Lee, Trinity, Colby, Union, Oberlin, Skidmore, Bowdoin, and

College of Holy Cross. 
Table 5. Trends in Inequality in Total Publications, 1991-2007

\begin{tabular}{|c|c|c|c|c|c|c|c|c|c|c|c|c|c|c|}
\hline \multirow[b]{2}{*}{ Year } & \multicolumn{2}{|c|}{ All } & \multicolumn{2}{|c|}{ Top-PhD } & \multicolumn{2}{|c|}{ Mid-PhD } & \multicolumn{2}{|c|}{ Rest-PhD } & \multicolumn{2}{|c|}{ Master's } & \multicolumn{2}{|c|}{ Liberal Arts } & \multicolumn{2}{|c|}{ Other } \\
\hline & Gini* & $\mathrm{CV}^{*}$ & Gini & $\mathrm{CV}$ & Gini & $\mathrm{CV}$ & Gini* & $\mathrm{CV}^{*}$ & Gini* & $\mathrm{CV}^{*}$ & Gini & $\mathrm{CV}$ & Gini* & $\mathrm{CV}$ \\
\hline 1991 & 0.83 & 2.41 & 0.27 & 0.48 & 0.23 & 0.41 & 0.37 & 0.68 & 0.48 & 0.93 & 0.56 & 1.08 & 0.83 & 2.49 \\
\hline 1992 & 0.83 & 2.45 & 0.28 & 0.51 & 0.20 & 0.35 & 0.37 & 0.68 & 0.49 & 0.93 & 0.60 & 1.16 & 0.82 & 2.42 \\
\hline 1993 & 0.82 & 2.39 & 0.27 & 0.49 & 0.22 & 0.41 & 0.36 & 0.68 & 0.45 & 0.85 & 0.53 & 1.10 & 0.79 & 2.21 \\
\hline 1994 & 0.81 & 2.34 & 0.28 & 0.52 & 0.22 & 0.42 & 0.33 & 0.63 & 0.43 & 0.81 & 0.53 & 1.02 & 0.80 & 2.23 \\
\hline 1995 & 0.80 & 2.28 & 0.28 & 0.52 & 0.20 & 0.35 & 0.31 & 0.57 & 0.43 & 0.78 & 0.53 & 1.01 & 0.78 & 2.06 \\
\hline 1996 & 0.80 & 2.30 & 0.27 & 0.49 & 0.20 & 0.36 & 0.33 & 0.60 & 0.41 & 0.76 & 0.49 & 0.90 & 0.77 & 2.04 \\
\hline 1997 & 0.80 & 2.30 & 0.28 & 0.51 & 0.20 & 0.38 & 0.31 & 0.56 & 0.44 & 0.85 & 0.53 & 1.04 & 0.77 & 2.08 \\
\hline 1998 & 0.80 & 2.28 & 0.27 & 0.51 & 0.20 & 0.36 & 0.33 & 0.59 & 0.43 & 0.79 & 0.51 & 0.99 & 0.76 & 2.04 \\
\hline 1999 & 0.81 & 2.32 & 0.28 & 0.52 & 0.21 & 0.37 & 0.32 & 0.59 & 0.41 & 0.77 & 0.51 & 0.95 & 0.78 & 2.13 \\
\hline 2000 & 0.80 & 2.32 & 0.29 & 0.52 & 0.20 & 0.35 & 0.31 & 0.55 & 0.45 & 0.84 & 0.54 & 1.01 & 0.76 & 2.10 \\
\hline 2001 & 0.81 & 2.34 & 0.28 & 0.53 & 0.21 & 0.37 & 0.30 & 0.54 & 0.44 & 0.79 & 0.54 & 1.07 & 0.80 & 2.42 \\
\hline 2002 & 0.81 & 2.35 & 0.28 & 0.50 & 0.18 & 0.33 & 0.33 & 0.60 & 0.44 & 0.80 & 0.66 & 1.34 & 0.78 & 2.11 \\
\hline 2003 & 0.81 & 2.29 & 0.26 & 0.47 & 0.21 & 0.38 & 0.31 & 0.55 & 0.46 & 0.86 & 0.52 & 1.01 & 0.78 & 2.25 \\
\hline 2004 & 0.80 & 2.33 & 0.28 & 0.52 & 0.21 & 0.38 & 0.31 & 0.56 & 0.46 & 0.83 & 0.55 & 1.24 & 0.77 & 2.20 \\
\hline 2005 & 0.81 & 2.28 & 0.27 & 0.50 & 0.22 & 0.39 & 0.32 & 0.57 & 0.43 & 0.81 & 0.56 & 1.09 & 0.77 & 2.18 \\
\hline 2006 & 0.81 & 2.35 & 0.31 & 0.58 & 0.18 & 0.33 & 0.32 & 0.57 & 0.42 & 0.77 & 0.50 & 0.95 & 0.77 & 2.24 \\
\hline 2007 & 0.81 & 2.27 & 0.27 & 0.48 & 0.21 & 0.39 & 0.33 & 0.60 & 0.44 & 0.81 & 0.54 & 1.08 & 0.77 & 2.11 \\
\hline
\end{tabular}

* Statistically significant trend at the 5 percent level or better as determined based on a regression of the ratio as a function of a time trend and constant, estimated over the full 17-year period.

Notes: Data sourced from Thomson Reuters Web of Knowledge (formerly referred to as ISI Web of Science). 
Table 6. Decomposition of GE(2) Across All Tiers

\begin{tabular}{|c|c|c|c|c|c|c|}
\hline \multirow[b]{2}{*}{ Year } & \multicolumn{3}{|c|}{ All Publications } & \multicolumn{3}{|c|}{ Top Publications } \\
\hline & $\begin{array}{l}\text { Overall } \\
\text { Inequality }^{\mathrm{a} *}\end{array}$ & $\begin{array}{l}\text { Within Tier } \\
\text { Inequality }\end{array}$ & $\begin{array}{l}\text { Between Tier } \\
\text { Inequality* }\end{array}$ & $\begin{array}{l}\text { Overall } \\
\text { Inequality }^{\text {a }}\end{array}$ & $\begin{array}{l}\text { Within Tier } \\
\text { Inequality }\end{array}$ & $\begin{array}{l}\text { Between Tier } \\
\text { Inequality }\end{array}$ \\
\hline 1991 & 2.91 & 0.70 & 2.21 & 6.71 & 2.35 & 4.36 \\
\hline 1992 & 2.99 & 0.74 & 2.26 & 6.82 & 2.40 & 4.42 \\
\hline 1993 & 2.85 & 0.69 & 2.16 & 6.94 & 2.56 & 4.38 \\
\hline 1994 & 2.74 & 0.71 & 2.03 & 6.16 & 2.29 & 3.87 \\
\hline 1995 & 2.60 & 0.65 & 1.96 & 6.75 & 2.40 & 4.34 \\
\hline 1996 & 2.65 & 0.63 & 2.02 & 6.96 & 2.49 & 4.47 \\
\hline 1997 & 2.65 & 0.65 & 2.00 & 6.21 & 2.18 & 4.03 \\
\hline 1998 & 2.59 & 0.64 & 1.95 & 6.38 & 2.43 & 3.95 \\
\hline 1999 & 2.70 & 0.67 & 2.03 & 5.71 & 1.88 & 3.83 \\
\hline 2000 & 2.70 & 0.67 & 2.03 & 7.29 & 2.94 & 4.35 \\
\hline 2001 & 2.73 & 0.69 & 2.04 & 6.56 & 2.14 & 4.41 \\
\hline 2002 & 2.76 & 0.66 & 2.11 & 6.18 & 1.97 & 4.22 \\
\hline 2003 & 2.61 & 0.59 & 2.02 & 6.92 & 2.54 & 4.39 \\
\hline 2004 & 2.70 & 0.69 & 2.02 & 6.35 & 2.14 & 4.21 \\
\hline 2005 & 2.59 & 0.63 & 1.96 & 7.33 & 2.71 & 4.61 \\
\hline 2006 & 2.76 & 0.76 & 2.00 & 7.22 & 3.04 & 4.18 \\
\hline 2007 & 2.58 & 0.61 & 1.97 & 6.31 & 2.24 & 4.08 \\
\hline
\end{tabular}

${ }^{a}$ Overall inequality is measured in this table as GE(2). It is equivalent to $1 / 2 * \mathrm{CV}$ squared. $\mathrm{CV}$ is reported in Table 5.

* Statistically significant trend at the 5 percent level or better as determined based on an OLS regression of the ratio as a function of a time trend and constant estimated over the full 17-year period.

Notes: Data sourced from Thomson Reuters Web of Knowledge (formerly referred to as ISI Web of Science). 
Table 7. Ratios of Mean Publications by Tier and Period

Panel A: Total Publications

\begin{tabular}{|c|c|c|c|c|c|c|c|c|c|c|c|c|}
\hline Period & $\begin{array}{l}\text { Top-PhD/ } \\
\text { Mid-PhD }\end{array}$ & $\begin{array}{l}\text { Mid-PhD/ } \\
\text { Rest-PhD* }\end{array}$ & $\begin{array}{l}\text { Mid-PhD/ } \\
\text { Liberal Arts }\end{array}$ & $\begin{array}{l}\text { Mid-PhD/ } \\
\text { Master's }\end{array}$ & $\begin{array}{l}\text { Mid-PhD/ } \\
\text { Other }\end{array}$ & $\begin{array}{l}\text { Top-PhD/ } \\
\text { Rest-PhD* }\end{array}$ & $\begin{array}{l}\text { Rest-PhD/ } \\
\text { Liberal Arts }\end{array}$ & $\begin{array}{l}\text { Rest-PhD/ } \\
\text { Master's }\end{array}$ & $\begin{array}{l}\text { Rest-PhD/ } \\
\text { Other }\end{array}$ & $\begin{array}{l}\text { Lib. Arts/ } \\
\text { Master's }\end{array}$ & $\begin{array}{l}\text { Lib. Arts/ } \\
\text { Other }\end{array}$ & $\begin{array}{l}\text { Master's/ } \\
\text { Other }\end{array}$ \\
\hline 1991-1993 & 1.67 & 2.58 & 25.42 & 6.57 & 38.23 & 4.31 & 9.87 & 2.55 & 14.83 & 0.26 & 1.50 & 5.82 \\
\hline 1994-1996 & 1.72 & 2.37 & 24.98 & 5.49 & 30.11 & 4.09 & 10.53 & 2.31 & 12.69 & 0.22 & 1.21 & 5.48 \\
\hline 1997-1999 & 1.68 & 2.37 & 22.47 & 5.85 & 30.81 & 4.00 & 9.46 & 2.46 & 12.97 & 0.26 & 1.37 & 5.27 \\
\hline $2000-2002$ & 1.70 & 2.45 & 23.51 & 5.99 & 31.83 & 4.17 & 9.59 & 2.44 & 12.97 & 0.25 & 1.35 & 5.32 \\
\hline 2003-2005 & 1.71 & 2.25 & 21.46 & 6.00 & 31.61 & 3.84 & 9.54 & 2.67 & 14.05 & 0.28 & 1.47 & 5.26 \\
\hline $2006-2007$ & 1.64 & 2.34 & 24.32 & 5.76 & 33.46 & 3.84 & 10.38 & 2.46 & 14.28 & 0.24 & 1.38 & 5.81 \\
\hline \multicolumn{13}{|c|}{ Panel B: Top Publications } \\
\hline Period & $\begin{array}{l}\text { Top-PhD/ } \\
\text { Mid-PhD }\end{array}$ & $\begin{array}{l}\text { Mid-PhD/ } \\
\text { Rest-PhD* }\end{array}$ & $\begin{array}{l}\text { Mid-PhD/ } \\
\text { Liberal Arts }\end{array}$ & $\begin{array}{l}\text { Mid-PhD/ } \\
\text { Master's }\end{array}$ & $\begin{array}{l}\text { Mid-PhD/ } \\
\text { Other }\end{array}$ & $\begin{array}{l}\text { Top-PhD/ } \\
\text { Rest-PhD* }\end{array}$ & $\begin{array}{l}\text { Rest-PhD/ } \\
\text { Liberal Arts }\end{array}$ & $\begin{array}{l}\text { Rest-PhD/ } \\
\text { Master's }\end{array}$ & $\begin{array}{l}\text { Rest-PhD/ } \\
\text { Other }\end{array}$ & $\begin{array}{l}\text { Lib. Arts/ } \\
\text { Master's }\end{array}$ & $\begin{array}{l}\text { Lib. Arts/ } \\
\text { Other }\end{array}$ & $\begin{array}{l}\text { Master's/ } \\
\text { Other }\end{array}$ \\
\hline 1991-1993 & 2.67 & 4.09 & 31.65 & 12.46 & 74.08 & 10.94 & 7.74 & 3.05 & 18.12 & 0.39 & 2.34 & 5.94 \\
\hline 1994-1996 & 2.67 & 3.53 & 41.11 & 13.84 & 67.46 & 9.43 & 11.65 & 3.92 & 19.11 & 0.34 & 1.64 & 4.87 \\
\hline 1997-1999 & 2.53 & 3.41 & 38.49 & 12.10 & 63.02 & 8.62 & 11.28 & 3.55 & 18.48 & 0.31 & 1.64 & 5.21 \\
\hline $2000-2002$ & 2.75 & 3.54 & 44.25 & 13.87 & 69.66 & 9.71 & 12.51 & 3.92 & 19.69 & 0.31 & 1.57 & 5.02 \\
\hline $2003-2005$ & 3.13 & 3.23 & 39.15 & 11.73 & 54.48 & 10.13 & 12.11 & 3.63 & 16.85 & 0.30 & 1.39 & 4.64 \\
\hline $2006-2007$ & 2.69 & 3.36 & 42.47 & 11.15 & 70.94 & 9.05 & 12.63 & 3.32 & 21.10 & 0.26 & 1.67 & 6.36 \\
\hline
\end{tabular}

* Statistically significant trend at the 5 percent level or better as determined based on an OLS regression of the ratio as a function of a time trend and constant, estimated over the full 17-year period.

Notes: Data sourced from Thomson Reuters Web of Knowledge (formerly referred to as ISI Web of Science). 
Appendix Table 1. Listing of Institutions by Tier ${ }^{a}$

\begin{tabular}{|c|c|}
\hline Top-PhD & Mid-PhD \\
\hline Boston University & Arizona State University \\
\hline Brown & Boston College \\
\hline Cal Tech & Georgetown University \\
\hline Carnegie Mellon Univ. & Indiana University \\
\hline Chicago & lowa State University \\
\hline Columbia & Michigan State University \\
\hline Cornell & North Carolina State University \\
\hline Duke & Purdue University \\
\hline Harvard & Rice University \\
\hline John Hopkins Univ. & Rutgers University-New Brunswick \\
\hline Maryland & Syracuse University \\
\hline Michigan & Texas A \& M University \\
\hline Minnesota & University Of Arizona \\
\hline MIT & University Of California-Davis \\
\hline Northwestern & University Of California-Irvine \\
\hline NYU & University Of California-Santa Barbara \\
\hline Ohio State & University Of Colorado At Boulder \\
\hline Penn State University & University Of Florida \\
\hline Princeton & University of Illinois At Urbana \\
\hline Rochester & University Of lowa \\
\hline Stanford & University Of North Carolina At Chapel Hill \\
\hline UC-Berkeley & University Of Pittsburgh \\
\hline UCLA & University Of Southern California \\
\hline UC-San Diego & University Of Washington \\
\hline Upenn & Vanderbilt University \\
\hline \multicolumn{2}{|l|}{ UT-Austin } \\
\hline \multicolumn{2}{|l|}{ Virginia } \\
\hline Washington University in St. Louis & \\
\hline Wisconsin & \\
\hline
\end{tabular}

\begin{tabular}{l} 
Rest-PhD \\
\hline American University \\
Brandeis University \\
Claremont Graduate School \\
Clark University \\
Clemson University \\
Colorado School of Mines \\
Colorado State University \\
Cuny Graduate School And University Center \\
Drexel University \\
Emory University \\
Florida International University \\
Florida State University \\
Fordham University \\
George Mason University \\
George Washington University \\
Georgia Institute Of Technology \\
Georgia State University
\end{tabular}

Master's

Select Liberal Arts

Bowling Geen Ste University

California Polytechnic State Univ-San Luis Obispı Bates College

California State Polytechnic University-Pomona Beloit College

California State University-East Bay Bowdoin College

California State University-Fullerton Bryn Mawr College

California State University-Long Beach Bucknell University

California State University-Los Angeles Carleton College

California State University-Sacramento Centre College

Catholic University

Central Michigan University

Cleveland State University

Cuny Bernard M Baruch College

Claremont Mckenna College

Colgate University

Cuny Brooklyn College Colorado College

Cuny City College Connecticut College

Howard University

Indiana University Purdue University Indianapolis

Kansas State Univ

Lehigh University

Louisiana State $U$

Middle Tennessee State University

Mississippi State University

New School For Social Research

Northeastern University

Northern Illinois University

Oklahoma State University-Main Campus

Oregon State University

Rensselaer Polytechnic Institute

Southern Illinois University-Carbondale

Southern Methodist University

Suffolk University

Suny At Albany

Suny At Binghamton

Suny At Buffalo

Suny At Stony Brook

Teachers College At Columbia University

Temple University

Texas Tech University

Tulane University

University Of Alabama

University of Arkansas

University of California-Riverside

University Of California-Santa Cruz

University Of Central Florida

University of Connecticut

University of Delaware

University Of Georgia

University Of Hawaii At Manoa

University Of Houston

University Of Illinois At Chicago

University Of Kansas

University Of Kentucky

University of Massachusetts-Amherst

University of Miami

University Of Mississippi

University of Missouri-Columbia

University of Missouri-Kansas City

University Of Nebraska

University Of Nevada

University of New Hampshire

University of New Mexico

University of North Carolina At Greensboro

University Of Notre Dame

University Of Oklahoma Norman Campus

Depaul University

East Carolina University

Eastern Illinois University

Eastern Michigan University

Florida Atlantic University

Illinois State University

Kent State University

Michigan Technological University

Montana State University

Morgan State University

Murray State University

New Mexico State University

North Dakota State University

Ohio University Main Campus

Old Dominion University

Pace University

Portland State University

Roosevelt University

Saint Cloud State University

San Diego State University

San Francisco State University

San Jose State University

South Dakota State University

Southern Illinois University-Edwardsville

Tufts University

University of Akron Main Campus

University of Alaska Fairbanks

University of Cincinnati

University of Colorado

University of Denver

University Of Idaho

University of Maine

Denison University

Depauw University

Dickinson College

Franklin And Marshall College

Furman University

Grinnell College

Hamilton College

Haverford College

Kenyon College

Lafayette College

Lawrence University

Macalester College

Middlebury Colle

Mount Holyoke College

Oberlin College

Occidental College

Pomona College

Rhodes College

Sarah Lawrence College

Scripps College

Skidmore College

Smith College

Swarthmore College

Trinity College

Union College

University of The South

Vassar College

Washington And Lee University

Wellesley College

Wesleyan University

Wheaton College

University Of Maryland-Baltimore County_ Willamette University

University of Memphis

Williams

University of Missouri-St Louis

University of Montana-Missoula

University of Nebraska At Omaha

University of Nevada-Las Vegas

University Of North Carolina At Charlotte

University Of North Dakota-Main Campus

University Of North Texas

University of San Francisco

University of Texas At Arlington

University of Texas At El Paso

University Of Texas At San Antonio

University of Toledo

Virginia Commonwealth University

Virginia State University

West Texas A \& M University

Western Illinois University

Wichita State University

Williams College

Wright State University

Youngstown State University

University Of South Florida

University Of Tennessee

University of Texas At Dallas

University Of Utah

University Of Wisconsin-Milwaukee

University of Wyoming

Utah State University

Virginia Polytechnic Institute And State Univ

Washington State University

Wayne State University

West Virginia University

Western Michigan University 
Appendix Table 2. Top 30 Institutions, Selected Rankings

\begin{tabular}{|c|c|c|c|c|c|c|c|}
\hline & \multicolumn{5}{|c|}{ Economics PhD } & \multicolumn{2}{|c|}{ Business School } \\
\hline & $\begin{array}{l}\text { US News\&World } \\
\text { Report, } 2009\end{array}$ & NRC 2010 & NRC 1995 & $\begin{array}{r}\text { Kalaitzidakis } \\
\text { et al., } 2003\end{array}$ & $\begin{array}{c}\text { Amir \& Knauff, } \\
2008\end{array}$ & $\begin{array}{l}\text { US News\&World } \\
\text { Report, } 2009\end{array}$ & $\begin{array}{r}\text { Forbes } \\
2005\end{array}$ \\
\hline Yale & 1 & $6-15$ & 6 & 6 & 6 & 11 & 5 \\
\hline Chicago & 2 & $1-3$ & 2 & 2 & 5 & 5 & 3 \\
\hline Harvard & 3 & $1-2$ & 1 & 1 & 2 & 1 & 7 \\
\hline MIT & 4 & $2-5$ & 3 & 3 & 1 & 3 & 18 \\
\hline Stanford & 5 & $6-13$ & 4 & 8 & 3 & 2 & 6 \\
\hline UC-Berkeley & 6 & $3-8$ & 7 & 9 & 7 & 8 & 15 \\
\hline Princeton & 7 & $4-11$ & 5 & 7 & 4 & NA & NA \\
\hline UCLA & 8 & $13-25$ & 11 & 14 & 14 & 15 & 19 \\
\hline Northwestern & 9 & $10-17$ & 9 & 4 & 9 & 4 & 10 \\
\hline Michigan & 10 & $14-27$ & 13 & 13 & 16 & 12 & 26 \\
\hline Minnesota & 11 & $14-25$ & 10 & 19 & 8 & 26 & NA \\
\hline Columbia & 12 & $8-19$ & 12 & 11 & 18 & 9 & 4 \\
\hline Upenn & 13 & $7-18$ & 8 & 5 & 11 & 6 & 2 \\
\hline NYU & 14 & $5-14$ & 17 & 10 & 25 & 10 & 13 \\
\hline Wisconsin & 15 & $8-17$ & 15 & 18 & 15 & 30 & NA \\
\hline Cal Tech & 16 & $16-26$ & 19 & 26 & 19 & NA & NA \\
\hline UC-San Diego & 17 & $17-30$ & 16 & 12 & 20 & NA & NA \\
\hline Cornell & 18 & $19-29$ & 18 & 15 & 27 & 18 & 9 \\
\hline Duke & 19 & $18-29$ & 22 & 22 & 17 & 14 & 20 \\
\hline Virginia & 20 & NA & 24 & NA & 28 & 13 & 8 \\
\hline UT-Austin & 21 & $25-48$ & 31 & 16 & NA & 17 & 11 \\
\hline Carnegie Mellon Univ. & 22 & $22-47$ & NA & 24 & 12 & 16 & 16 \\
\hline Maryland & 23 & $5-18$ & 20 & 25 & 22 & NA & 29 \\
\hline Penn State University & 24 & $26-46$ & 45 & NA & 21 & NA & 23 \\
\hline Rochester & 25 & $22-36$ & 14 & 17 & 13 & 29 & NA \\
\hline Washington University in & 26 & $17-26$ & 29 & NA & NA & 20 & 27 \\
\hline Ohio State & 27 & $22-34$ & 35 & 29 & NA & 21 & NA \\
\hline Boston University & 28 & $25-63$ & 21 & 20 & 29 & NA & NA \\
\hline Brown & 29 & $14-24$ & 23 & 21 & 24 & NA & NA \\
\hline John Hopkins Univ. & 30 & $24-44$ & 32 & NA & 23 & NA & NA \\
\hline
\end{tabular}

NRC 2010 ranking is calculated using the regression-based score set equal to 5, range shown is 5th-95th percentile, based on 29 April 2011 revision. 
Appendix Table 3. PhD Institutions categorized using NRC 2010

Top PhD ( $\mathrm{n}=30$, includes selected elite)

All Publications
Share

\begin{tabular}{c} 
Mid PhD $(\mathrm{n}=25)$ \\
\hline Share
\end{tabular}

Rest PhD $(n=80)$
Share

\section{Period}

1991-1993

\begin{tabular}{cccrcrr} 
Mean & SD & Median & of Total & & Mean & Total \\
\hline \hline 81.1 & 41.3 & 83.0 & 0.38 & & 19.2 & 0.57
\end{tabular}

Mean SD Median of Total

Mean

1994-1996

1997-1999

2000-2002

$\begin{array}{llllll}83.4 & 44.1 & 80.5 & 0.36 & 18.5 & 0.56\end{array}$

$\begin{array}{llll}44.0 & 22.2 & 43.0 & 0.17\end{array}$

Total

M

Mean SD Median of Total

$\begin{array}{llll}44.6 & 21.8 & 44.0 & 0.16\end{array}$

6.3

0.16

20.9

14.3

18.0

$=$

Mean Total

$\begin{array}{llllll}82.6 & 44.4 & 77.0 & 0.36 & 18.8 & 0.53\end{array}$

46.2

$21.9 \quad 46.0 \quad 0.17$

6.7

0.16

21.0

0.26

$\begin{array}{llll}47.1 & 23.0 & 50.0 & 0.16\end{array}$

7.2

0.15

$\begin{array}{llll}53.7 & 26.5 & 55.0 & 0.16\end{array}$

7.3

0.14

$23.1 \quad 12.9$

$21.0-0.26$

$\begin{array}{llll}60.0 & 31.1 & 60.0 & 0.16\end{array}$

8.1

0.15

$\begin{array}{lll}27.1 & 14.6 \quad 27.0\end{array}$

$30.4 \quad 16.6 \quad 30.0$

0.26

0.27

0.27

\begin{tabular}{cc} 
Mean & Total \\
\hline 2.0 & 0.16
\end{tabular}

2.20 .18

$2.6 \quad 0.20$

2003-2005

Notes: NRC 2010 ranking is calculated using the regression-based score set equal to 5, based on 29 April 2011 revision.

Data sourced from Thomson Reuters Web of Knowledge (formerly referred to as ISI Web of Science). 